\title{
BOBOT POTONG, KARKAS, GIBLET DAN LEMAK ABDOMINAL AYAM BROILER YANG TEMULAWAK (Curcumaxanthorrhiza, Roxb) DALAM PAKAN
}

\author{
Sri Jumiati ${ }^{1}$, Nuraini ${ }^{2}$, dan Rahim Aka ${ }^{2}$ \\ ${ }^{1}$ Alumni Jurusan Peternakan, Fakultas Peternakan, UHO \\ ${ }^{2}$ Dosen Fakultas Peternakan, UHO \\ e-mail: srijumiati04@yahoo.com
}

\begin{abstract}
ABSTRAK
Penelitian tentang bobot potong, karkas, giblet dan lemak abdominal ayam broiler yang diberi temulawak (Curcuma xanthorrhiza Roxb) dalam pakan menggunakan 80 ekor ayam broiler yang dipelihara selama 5 (lima) minggu menggunakan strain CP 707 dengan pakan komersial BP-11 dan temulawak. Penelitian menggunakan rancangan acak lengkap (RAL) dengan 4 perlakuan: P0 (BP-11 tanpa temulawak), P1 (BP-11 + temulawak 1\%), P2 (BP-11 + temulawak 2\%), P3 (BP-11 + temulawak 3\%) dengan 4 ulangan. Variabel yang diteliti adalah bobot potong, persentase karkas, giblet dan lemak abdominal ayam broiler. Hasil penelitian menumjukkan bahwa pemberian tepung temulawak dalam pakan memberikan pengaruh nyata terhadap bobot potong dan persentase lemak abdominal, namun tidak menunjukkan pengaruh nyata terhadap persentase karkas dan persentase giblet.
\end{abstract}

Kata Kunci : Ayam broiler, Temulawak, Bobot potong, Karkas, Giblet dan Lemak abdominal.

\begin{abstract}
The research about slaughter weight, carcass, giblet, and abdominal fat of broiler chicken fed with temulawak (Curcuma xanthorrhiza, Roxb) in feed used 80 of chicken broiler strain CP 707 raised for 5 weeks and fed with commercial feed BP-11 and temulawak.This research used completely randomized design with 4 treatments: P0 (BP-11 without temulawak), P1 (BP-11 + temulawak 1\%), P2 (BP-11 + temulawak 2\%), and P3 (BP-11 + temulawak 3\%) and 4 replications. Measured variables were slaughtering weight, carcass weight, giblet, and abdominal fat of broiler chicken. Result of the study showed that additional of temulawak meal in feed gave a significant effect on slaughtering weight and abdominal fat percentage, but did not gave effect on carcass and giblet percentage.
\end{abstract}

Key words : Broiler chicken, Temulawak, Slaughtering weight, Carcass, Giblet, and Abdominal fat

\section{PENDAHULUAN}

Broiler adalah ayam tipe pedaging yang paling umum diternakkan untuk menghasilkan daging dalam jangka waktu yang singkat yaitu dapat dipelihara dalam waktu 21-35 hari. Ayam broiler masih menjadi prioritas utama untuk memenuhi kebutuhan protein hewani manusia, yaitu pada tahun 2012, daging ayam broiler berkontribusi $84,4 \%$ terhadap kebutuhan daging unggas nasional. Berbagai upaya dilakukan peternakuntuk meningkatkan produktifitas ayam broiler, seperti perbaikan tata laksana pemeliharaan perkandangan dan pakan termasuk penambahan feed additive.

Pakan merupakan salah satu aspek penting dalam usaha ayam broiler selain bibit, disamping itu pakan dari segi finansial juga merupakan faktor yang memiliki peranan paling besar dalam struktur biaya produksi dibandingkan dengan faktor-faktor lainnya. 
Penggunaan pakan pada produksi ayam broiler mencapai sekitar $60-70 \%$ dari total biaya produksi. Untuk menunjang laju pertumbuhan yang cepat dari ayam broiler maka diperlukan feed additive yang ditambahkan dalam bahan pakan. Pakan tambahan pelengkap (feed additive) tersebut untuk memacu pertumbuhan yang lebih baik atau produksi daging yang tinggi sebesar 66,8\%. Selain laju pertumbuhan yang cepat pada broiler selalu diikuti perlemakan yang cepat,dimana penimbunan lemak yang cenderung meningkat sejalan dengan bertambahnya umur. Oleh karena perlunya penambahan feed additive dalam pakan untuk mengurangi penimbunan lemak dalam tubuh.

Untuk menekan biaya pakan, diperlukan adanya usaha-usaha yang efisien dalam pemanfaatan pakan untuk ternak, agar peningkatan pendapatan dapat dicapai sesuai yang diharapkan, baik pakan jadi atau melalui asupan tambahan seperti feed additive. Oleh karena itu, perlu dicari alternatif bahan alami untuk menggantikan suplemen yang berasal dari bahan kimia sintetis.Salah satu suplemen alami yang dapat digunakan sebagai pengganti suplemen sintetis yaitu dari jenis tanaman yang mengandung antibiotik alami seperti temulawak.

Temulawak

(Curcuma xanthorrhiza, Roxb) merupakan tanaman herbal yang termasuk kedalam golongan antibiotik alami dan tidak mengakibatkan residu atau berbahaya apabila dikonsumsi oleh ternak maupun manusia.Komponen utama pada rimpang temulawak yang berkhasiat obat adalah minyak atsiri dan zat warna kuning (kurkuminoid). Senyawa kurkuminoid mempunyai khasiat antibakteri yang dapat meningkatkan proses pencernaan dengan membunuh bakteri yang merugikan (patogen) seperti bakteri Haemophilus paragallinarum biasa dikenal dengan infectious coryza (snot), pasteurella multocida (Fowl cholera) serta merangsang dinding kantong empedu untuk mengeluarkan cairan empedu sehingga dapat memperlancar metabolisme lemak (Sufiriyanto dan Indradji, 2007).

Sejalan dengan upaya untuk mengkaji pengaruh pemberian temulawak dalam pakan maka perlu dilakukan penelitian tentang produksi, terhadap produksi bobot potong, karkas, giblet dan lemak abdominal ayam pedaging maka perlu untuk dilakukan penelitian ini.

\section{MATERI DAN METODE}

\section{Waktu dan Tempat}

Penelitian ini telah dilaksanakan selama 1 (satu) bulan yaitu bulan Desember 2016 sampai Januari 2017, bertempat di Unit Kandang Unggas Fakultas Peternakan, Universitas Halu Oleo, Kendari.

\section{Materi Penelitian}

Penelitian ini menggunakan 80 ekor ayam broiler strain CP 707 dengan mengunakan pakan komersial BP-11 produksi PT. Charoen Phokpand Makassar dan temulawak.

\section{Rancangan Penelitian}

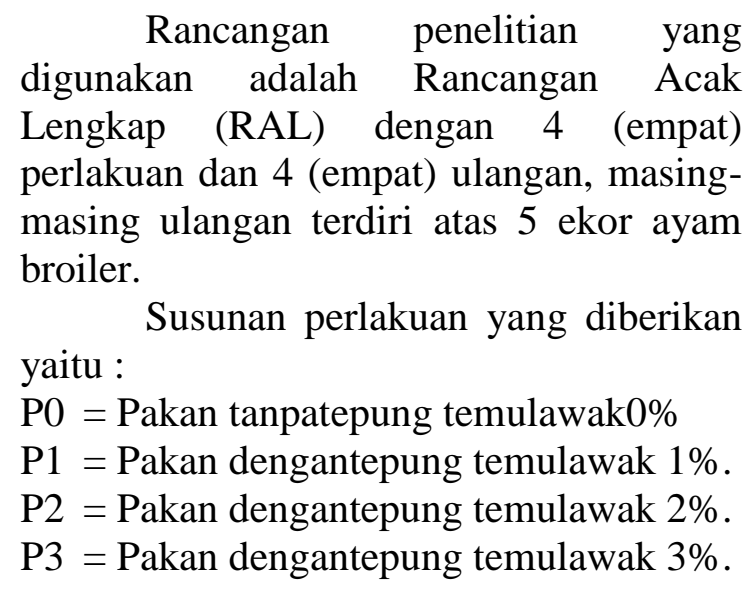

\section{Variabel Penelitian}

Variabel yang ditelliti dalam penelitian ini adalah:

1. Bobot potong

2. Persentase karkas

3. Persentase rempela 
4. Persentase hati

5. Persentase jantung, dan

6. Persentase lemak abdominal

\section{Analisis Data}

Data yang diperoleh meliputi bobot potong, persentase karkas, giblet dan persentase lemak abdominal dapat dihitung dengan rumus sebagai berikut :

1. Bobot Potong (gram)

Bobot potong adalah hasil penimbangan ayam sebelum potong setelah sebelumnya dipuasakan dari pakan selama 4 jam (air minum tetap diberikan).

\section{Persentase Karkas (\%)}

Karkas adalah hasil pemotongan ayam setelah dikeluarkan bulu, isi rongga perut, kepala dan kaki. Persentase karkas dapat dihitung dengan rumus sebagai berikut:

Persentase bobot karkas $(\%)=$

Bobot karkas (gram) x 100\%

Bobot hidup (gram)

\section{Persentase Giblet (\%)}

Bobot giblet dihitung dengan cara menimbang hati, jantung, dan rempela (gizzard) secara terpisah. Persentase masing-masing bobot giblet dapat dihitung dengan rumus sebagai berikut:

a. Persentase bobot rempela $(\%)=$

Bobot rempela (gram) x 100\%

Bobot hidup (gram) b. Persentase bobot hati $(\%)=$ Bobot hati (gram) x 100\%

Bobot hidup (gram)

c. Persentase bobot jantung $(\%)=$ Bobot jantung (gram) x 100\%

Bobot hidup (gram)

4. Lemak Abdominal (\%)

Pengukuran bobot lemak abdominal dilakukan dengan cara menimbang lemak yang didapat dari lemak yang berada pada sekeliling gizzarddan lapisan lemak yang menempel pada rongga perut dan selanjutnya ditimbang. Rumus persentase lemak abdominal yaitu:

Persentase bobot lemak abdominal (\%)

$=$ Bobot lemak abdominal (gram) $\times 100 \%$

Bobot hidup (gram)

Selanjutnya data yang diperoleh dianalisis dengan Analisis of Variance (ANOVA) dengan diuji $f$ hitung untuk mengetahui pengaruh perlakuan. Pelakuan yang berpengaruh nyata terhadap peruba akan dilanjutkan dengan uji Beda Nyata Terkecil (BNT).

\section{HASIL DAN PEMBAHASAN}

Rataan bobot potong, persentase karkas, giblet dan lemak abdominal ayam broiler pada penelitian ini dapat dilihat pada Tabel 1.

Tabel 1. Rata-rata Bobot Potong, Persentase Karkas, Giblet dan Lemak Abdominal Ayam Broiler yang Diberi Feed Additive Temulawak dalam Pakan.

\begin{tabular}{|c|c|c|c|c|}
\hline \multirow[b]{2}{*}{ Variabel yang diamati } & \multicolumn{4}{|c|}{ Perlakuan } \\
\hline & P0 (0\%) & P1 (1\%) & P2 (2\%) & P3 (3\%) \\
\hline Bobot Potong & $1800,25 \pm 36,87^{\mathrm{a}}$ & $1824,50 \pm 37,90^{\mathrm{a}}$ & $1867,25 \pm 83,91^{\mathrm{a}}$ & $1707,13 \pm 59,28^{b}$ \\
\hline Persentase Karkas & $76,46 \pm 4,91^{\mathrm{a}}$ & $76,95 \pm 5,35^{\mathrm{a}}$ & $76,47 \pm 2,55^{\mathrm{a}}$ & $75,83 \pm 1,17^{\mathrm{a}}$ \\
\hline Persentase Rempela & $1,29 \pm 0,22^{\mathrm{a}}$ & $1,26 \pm 0,05^{\mathrm{a}}$ & $1,38 \pm 0,14^{\mathrm{a}}$ & $1,46 \pm 0,25^{\mathrm{a}}$ \\
\hline Persentase Hati & $2,25 \pm 0,15^{\mathrm{a}}$ & $2,01 \pm 0,18^{\mathrm{a}}$ & $2,07 \pm 0,19^{\mathrm{a}}$ & $2,02 \pm 0,26^{\mathrm{a}}$ \\
\hline Persentase Jantung & $0,35 \pm 0,04^{a}$ & $0,40 \pm 0,04^{a}$ & $0,39 \pm 0,07^{\mathrm{a}}$ & $0,39 \pm 0,02^{\mathrm{a}}$ \\
\hline Lemak Abdominal & $1,93 \pm 0,23^{a}$ & $1,43 \pm 0,13^{b}$ & $1,48 \pm 0,23^{b}$ & $1,53 \pm 0,09^{b}$ \\
\hline
\end{tabular}

Keterangan : Superscript yang berbeda pada baris yang sama menunjukkan perngaruh yang nyata $(\mathrm{P}<0,05)$. 


\section{Bobot Potong}

Bobot potong adalah bobot yang didapat dengan cara menimbang bobot akhir ayam dan setelah dipuasakan selama \pm 4 jam. Rata-rata bobot potong ayam broiler pada penelitian ini berkisar antara $1707,13 \pm 59,28-1867,25 \pm 83,91$

gram/ekor.Rataan bobot potong tertinggi pada perlakuan P2 dan terendah pada perlakuan P3.Bobot potong yang diperoleh pada penelitian ini (P1 dan $\mathrm{P} 2$ ) lebih tinggi jika dibandingkan dengan standar rata-rata bobot potong yang dikeluarkan oleh Charoen Pokphan (2004) bahwa rataan bobot potong normal ayam broiler umur 5 minggu adalah 1.765 gram/ekor.

Hasil analisis ragam menunjukkan bahwa pemberian level tepung temulawak yang berbeda memberikan pengaruh yang nyata $(\mathrm{P}>0,05)$ terhadap bobot potong ayam broiler umur 5 minggu. Hal ini menunjukkan bahwa rataan bobot potong masing-masing perlakuan dalam penelitian ini berbeda secara statistik. Pemberian temulawak $1 \%$ dan $2 \%$ dalam pakan dapat meningkatkan bobot potong ayam broiler, namun menurun pada pemberian temulawak 3\%. Hal ini menunjukkan bahwa pada temulawak mengandung minyak atsiri apabila berlebihan diberikan pada ayam broiler maka pertambahan bobot badan ayam akan menurun. Palatabilitas pakan yang menurun menyebabkan konsumsi pakan juga menurun dan berimplikasi terhadap pertambahan bobot badan.Hal ini disebabkan karena minyak atsiri mempunyai rasa tajam dan bau yang khas dan dapat menyebabkan palatabilitas pakan juga menurun, sehingga berdampak terhadap konsumsi pakan. Sinurat, dkk.(2008) menyatakan bahwa penggunaan temulawak dalam pakan ayam broiler dapat meningkatkan performa ayam broiler sebagai akibat dari meningkatnya daya cerna zat gizi. Berdasarkan hasil penelitian Sariati (2017) yang menyatakan bahwa pertambahan bobot badan ayam broiler yang diberi tepung temulawak $1 \%$,
$2 \%$ dan $3 \%$ yaitu $57,21 \pm 2,61,57,28 \pm 1,33$

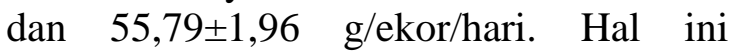
menunjukkan bahwa pemberian tepung temulawak (Curcuma xanthorrhiza, Roxb) 1-3\% memberikan pengaruh yang tidak nyata $(\mathrm{P}>0,05)$ terhadap pertambahan bobot badan ayam broiler. Sedangkan pada konsumsi pakan ayam broiler yang diberi tepung temulawak $1 \%, 2 \%$ dan $3 \%$ yaitu $104,16 \pm 5,42, \quad 102,75 \pm 1,05$ dan 100,62 $\pm 2,39$-g/ekor/hari. Hal ini menunjukkan bahwa pemberian tepung temulawak (Curcuma xanthorrhiza, Roxb) memberikan pengaruh yang tidak nyata $(\mathrm{P}>0,05)$ terhadap konsumsi pakan ayam broiler.

Temulawak didugamemberikan respon yang baik terhadap sistem ketahanan tubuh ayam danmenunjukkan adanya pengaruh terhadap pertumbuhan ayam broiler.Menurut Wijayakusuma (2005), temulawak seperti halnya kunyit, mempunyai khasiat pengobatan untuk berbagai penyakit. Temulawak juga memiliki sifat tonikum seperti kunyit yang berkhasiat sebagai penyegar dan meningkatkan stamina sehingga badan tidak cepat lelah dan sifat imunostimulan yang berfungsi untuk meningkatkan daya tahan tubuh serta menangkal berbagai serangan kuman penyebab penyakit, termasuk virus. Efek antioksidan kurkumin pada temulawak berfungsi untuk melindungi tubuh dari serangan radikal bebas yang berbahaya dan bersifat karsinogenik serta penyakit lainnya.

Hasil analisis lanjut dengan menggunakan uji Beda Nyata Terkecil (BNT) menunjukkan bahwa perlakuan P1 (temulawak 1\%) dan P2 (temulawak 2\%) tidak menunjukkan perbedaan yang signifikan $(\mathrm{P}>0,05)$ dengan $\mathrm{P} 0$ (tanpa temulawak), sedangkan P1 dan P2 juga sama-sama tidak menunjukkan perbedaan yang signifikan $(\mathrm{P}>0,05)$. Namun, perlakuan temulawak $3 \% \quad$ (P3) menunjukkan perbedaan yang sangat nyata $(\mathrm{P}<0,01)$ dengan perlakuan $\mathrm{P} 2$ (temulawak $2 \%$ ) dan menunjukkan perbedaan yang nyata $(\mathrm{P}<0,05)$ dengan perlakuan $\mathrm{P} 1$ 
(temulawak 1\%) dan P0 (tanpa temulawak). Hal ini berarti bahwa pemberian temulawak hingga $2 \%$ tidak menunjukkan perbedaan rata-rata bobot potong ayam broiler, namun pemberian dengan kadar temulawak $3 \%$ bisa menurunkan bobot potong ayam broiler karena menunjukkan perbedaan rata-rata yang signifikan.

\section{Persentase Karkas}

Persentase karkas seekor ayam erat hubungannya dengan bobot hidup ayam waktu panen. Selain itu, bagian dari ransum yang sangat berpengaruh untuk pembentukan karkas adalah kandungan protein ransum (Setiadi dkk., 2011). Rata-rata persentase karkas ayam broiler umur 5 minggu dengan level pemberian tepung temulawak yang berbeda berkisar antara75,83-76,95\% dari bobot potong, dengan rataan tertinggi pada perlakuan P1 dan terendah pada perlakuan P3. Penelitian ini lebih tinggi dari hasil penelitian Salam dkk.,(2013) bahwa persentase karkas bagian tubuh ayam broiler berkisar antara $65-75 \%$ dari bobot hidup. Menurut Suprayitno dan Indraji (2007) rataan persentase berat karkas ayam broiler umur 5 minggu adalah 59-63\% dari berat hidup. Sedangkan Sumarni (2015) menyatakan bahwa rataan persentase bobot karkas 69,76-73,39\%.

Hasil analisis ragam menunjukan bahwa pemberian level tepung temulawak yang berbeda tidak memberikan pengaruh yang nyata $(\mathrm{P}>0,05)$ pada persentase karkas ayam broiler umur 5 minggu. Hal ini menunjukkan bahwa rataan persentase karkas masing-masing perlakuan dalam penelitian ini tidak jauh berbeda secara statistik. Hal ini diduga bahwa temulawak tidak banyak berperan dalam menentukan persentase karkas ayam broiler, karena persentase karkas lebih dipengaruhi oleh pakan, umur, bangsa ternak, dan lingkungan. Menurut Subeki dkk. (2012) bahwa faktor yang mempengaruhi persentase karkas adalah bangsa, umur, jenis kelamin, pakan, kondisi fisik dan lemak abdominal.Menurut Mountney (1976) disitasi dalam Subeki dkk., (2012) menyatakan lemak dan jeroan merupakan hasil ikutan yang tidak dihitung dalam persentase karkas, jika lemak tinggi maka persentase karkas akan rendah. Dari segi pakan, menurut Setiadi dkk.(2011) bahwa bagian dari pakan yang sangat berpengaruh untuk pembentukan karkas adalah kandungan protein. Tingkat protein pakan sangat berpengaruh terhadap pencapaian bobot badan ternak. Hal ini menunjukkan bahwa protein berperan penting dalam pencapaian bobot karkas yang diinginkan sehingga dapat mempengaruhi persentase karkas.

\section{Persentase Rempela}

Rempela merupakan organ yang berperan penting untuk menghancurkan partikel-partikel makanan menjadi lebih kecil sehingga mudah untuk dicerna oleh ayam broiler. Rata-rata persentase rempela ayam broiler umur 5 minggu dengan level pemberian tepung temulawak yang berbeda berkisar antara 1,26 $\pm 0,05 \%$ $1,46 \pm 0,25 \%$ dari bobot potong, dengan rataan tertinggi pada perlakuan $\mathrm{P} 1$ dan terendah pada perlakuan P3. Rataan persentase rempela ayam broiler umur 5 minggu dalam penelitian ini masih dalam kisaran normal. Menurut Loth (2011) bahwa persentase gizzard (rempela) ayam broiler berkisar antara 1,23-1,39\%. Tuli dkk. (2014) memperoleh hasil penelitian yang lebih rendah bahwa persentase rempela (gizzard) ayam broiler berkisar antara 0,715-0,956\%. jika dibandingkan dengan Sturkie (2000) bahwa bobot rempela ayam broiler dengan pemberian tepung daun katuk dan knyit berkisar antara 1,6-2,3\% dari bobot hidup.

Hasil analisis ragam menunjukkan bahwa pemberian level tepung temulawak yang berbeda tidak memberikan pengaruh yang nyata $(\mathrm{P}>0,05)$ pada persentase rempela ayam broiler umur 5 minggu. Hal ini menunjukkan bahwa rataan persentase rempela masing-masing perlakuan dalam penelitian tidakberbeda secara statistik. 
Tidak adanya pengaruh yang signifikan pemberian tepung temulawak diduga dikarenakan temulawak tidak memberikan pengaruh terhadap pertumbuhan organ ayam broiler, namun pertumbuhan organ terutama rempela lebih dipengaruhi oleh faktor lain seperti aktivitas kerja rempela. Penggunaan jenis pakan yang sama dengan tekstur dan bentuk pakan yang sama mengakibatkan tidak adanya aktivitas yang berbeda pada rempela masing-masing perlakuan sehingga tidak ada perbedaan ukuran dan bobot rempela. Menurut Akoso (1993), besar kecilnya gizzard dipengaruhi oleh aktifitasnya, apabila ayam dibiasakan diberi pakan yang sudah digiling maka gizzardakan lisut. Siregar (2011) menambahkan bahwa penggunaan pakan yang sama dan konsumsi yang tidak berbeda pada penelitian ini membuat kerja rempela tidak berbeda pada setiap perlakuan sehingga persentase bobot rempela yang dihasilkan juga tidak berbeda. Bobot rempela ditentukan oleh bobot badan, serta jumlah, sifat, kekasaran tekstur dan kandungan serat kasar pakan. Pakan yang bertekstur keras akan membuat otot rempela lebih aktif bekerja dan kemudian menebal. Rempela yang lebih berat kerjanya lebih berat terhadap makanan yang diberikan seperti dikemukakan oleh Auza (2010), bahwa rempela dengan bobot yang lebih berat menandakan kerja rempela lebih berat pada bahan makanan yang diberikan.

\section{Persentase Hati}

Hati merupakan organ terbesar didalam tubuh.Hati memiliki beberapa fungsi yaitu pertukaran zat dari protein, lemak, sekresi empedu, detoksifikasi senyawa-senyawa yang beracun dan ekskresi senyawa-senyawa metabolit yang tidak berguna lagi. Ayam broiler yang memiliki hati normal akan tumbuh dengan baik. Rata-rata persentase hati ayam broiler umur 5 minggu dengan level pemberian tepung temulawak yang

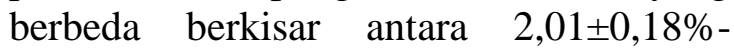
$2,25 \pm 0,15 \%$, dengan rataan tertinggi pada perlakuan P0 dan terendah pada perlakuan P1. Persentase hati yang didapatkan masih dalam kisaran normal.Hasil penelitian ini tidak jauh berbeda dengan Siregar (2011) bahwa rataan persentase bobot hati ayam broiler berkisar 1,98-2,12\% dari bobot potong. Sedangkan Suyanto dkk., (2013) menyatakan bahwa persentase hati ayam broiler yaitu $2,16 \%$ dari bobot badan. Khotimah (2002) menyatakan bahwa persentase hati diperoleh antara 2,152,59\%. Penelitian Sinurat et al., (2002) menyatakan bahwa persentase hati yaitu sebesar 2,21\% untuk ayam pedaging umur 35 hari dengan penambahan ampas mengkudu dalam ransum.

Hasil analisis ragam menunjukkan bahwa pemberian level tepung temulawak yang berbeda tidak memberikan pengaruh yang nyata $(\mathrm{P}>0,05)$ pada persentase hati ayam broiler umur 5 minggu. Presentase hati ayam broiler yaitu 2,16\% dari bobot badan (Suyanto dkk., 2013).Hal ini menunjukkan bahwa rataan persentase hati masing-masing perlakuan dalam penelitian ini tidakberbeda secara statistik.Tidak adanya perbedaan persentase hati ayam broiler pada penelitian ini diduga karena penggunaan temulawak tidak memberikan pengaruh yang berarti terhadap bobot hati ayam broiler.Pemberian temulawak hanya memberikan efek pengobatan dan pemeliharaan hati namun tidak berpengaruh pada bobot hati. Menurut Rukmana (2006), efek farmakologi temulawak dapat melindungi kerusakan hati (hepaprotektor), sebagai peluruh empedu dan sebagai penawar racun didalam tubuh.

\section{Persentase jantung}

Jantung adalah suatu struktur muscular berongga yang bentuknya menyerupai kerucut yang berfungsi memompakan darah ke dalam bilik-bilik atrial dan kemudian memompakan darah tersebut dari ventrikel menuju ke jaringan dan kembali lagi. Rata-rata persentase jantung ayam broiler umur 5 minggu dengan level pemberian tepung temulawak 
yang berbeda berkisar antara $0,35 \pm 0,04 \%$ $0,40 \pm 0,04 \%$, dengan rataan tertinggi pada perlakuan P1 dan terendah pada perlakuan P0. Hasil penelitian ini tidak jauh berbeda dengan Suyanto dkk. (2013) melaporkan bahwa persentase jantung ayam broiler yaitu $0,46-0,50 \%$, dengan rataan $0,47 \%$ dari bobot badan. Rata-rata berat jantung tiap perlakuan berada dibawah kisaran normal, bobot jantung rata-rata adalah 0,51,42\% dari bobot hidup (Nickle, 1977).

Hasil analisis ragam menunjukkan bahwa pemberian level tepung temulawak yang berbeda tidak memberikan pengaruh yang nyata $(\mathrm{P}>0,05)$ pada persentase jantung ayam broiler umur 5 minggu. Hal ini diduga bahwa temulawak tidak memberikan pengaruh yang berarti terhadap bobot jantung dan lebih dipengaruhi oleh faktor lain seperti aktivitas yang dilakukan oleh ayam broiler. Menurut Ressang (1993) menyatakan bahwa besar jantung tergantung dari jenis kelamin, umur, bobot badan, dan aktivitas hewan. Unggas umumnya memiliki ukuran jantung dan bervariasi, berat jantung ratarata adalah $0,5-1,42 \%$ dari berat hidup. Berdasarkan hasil pengamatan selama penelitian, aktivitas ayam pada setiap perlakuan relatif sama, jenis kelamin unsex, bobot badan yang relatifsama, dan umur broiler juga sama, sehingga hal ini berdampak terhadap bobot jantung untuk setiap perlakuan pada penelitian juga relatif sama. Proses metabolisme terjadi setelah pakan masuk ke tubuh unggas. Proses metabolisme ini akan mempengaruhi aktivitas kerja, rempela, hati, dan jantung. Unggas akan meningkatkan kemampuan metabolismenya untuk mencerna serat kasar sehingga meningkatkan ukuran rempela, hati, dan jantung (Hetland dkk., 2005).

\section{Persentase Lemak Abdominal}

Lemak abdominal merupakan salah satu komponen lemak tubuh ayam yang terdapat pada rongga perut. Lemak adominal didapat darilapisan yang membungkus organ pencernaan. Rata-rata persentase lemak abdominal broiler berkisar antara1,43 $\pm 0,13 \%-1,93 \pm 0,23 \%$ dengan persentase lemak tertinggi berada pada perlakuan P0 dan terendah pada perlakuan P1. Hasil penelitian ini lebih rendah jika dibandingkan dengan Mide (2007) yang memperoleh hasil penelitian bahwa persentase lemak abdominal ayam broiler yang diberikan temulawak dalam ransum berkisar antara 2,31-2.63\% .

Hasil analisis ragam menunjukkan bahwa pemberian level tepung temulawak yang berbeda memberikan pengaruh yang nyata $(\mathrm{P}<0,05)$ pada persentase lemak abdominal ayam broiler umur 5 minggu. Hal ini menunjukkan bahwa penggunaan tepung temulawak dapat menurunkan persentase lemak abdominal. Berdasarkan data pada Tabel 8, dapat dilihat bahwa dengan pemberian tepung temulawak dengan level $1-3 \%$ dapat menurunkan lemak abdominal.

Kecenderungan penurunan persentase lemak abdominal ini terkait dengan adanya peranan dari zat aktif kurkuminoid yang terkandung didalam temulawak. Mangisah (2005) menyatakan bahwa kurkuminoid temulawak mempunyai aktivitas kolagoga yang berfungsi meningkatkan produksi dan sekresi empedu. Riayadi (2002) menyatakan bahwa kurkumin temulawak dalam tubuh akan merangsang kantung empedu agar aktif mengeluarkan cairan empedu yang nantinya akan membantu pemecahan lemak.

$$
\text { Hasil uji lanjut Beda Nyata }
$$
Terkecil menunjukkan bahwa dalam perlakuan $(\mathrm{P} 0)$ berbeda nyata $(\mathrm{P}<0,05)$ dengan perlakuan P1, P2 dan P3. Namun, perlakuan $\mathrm{P} 1$ tidak berbeda nyata $(\mathrm{P}>0,05)$ dengan perlakuan $\mathrm{P} 2$ dan $\mathrm{P} 3$ serta perlakuan $\mathrm{P} 2$ tidak berbeda nyata dengan perlakuan P3. Hal ini menunjukkan bahwa pemberian temulawak $1-3 \%$ dapat menurunkan persentase lemak abdominal ayam broiler. Hal ini didukung dengan Afriastini (2011), menyatakan bahwa ramuan herbal mengandung zat bioaktif 
berupa minyak atsiri dan kurkumin yang dapat menurunkan lemak abdominal pada broiler. Minyak atsiri dan kurkumin yang dapat merangsang dinding kantong empedu dengan menetralkan kondisi asam dari saluran usus dan mengurangi pengemulsian lemak sehingga pembentukan lemak berkurang.

\section{KESIMPULAN}

Berdasarkan hasil penelitian dapat disimpulkan bahwa pemberian tepung temulawak dalam pakan memberikan pengaruh nyata terhadap bobot potongdan persentase lemak abdominal, namun tidak menunjukan pengaruh nyata terhadap persentase karkas dan persentase giblet.

\section{DAFTAR PUSTAKA}

Afriastini, J. J. 2011. Bertanam Kencur. Penebar Swadaya, Jakarta.

Akoso, B. T. 1993. Manual Kesehatan Unggas : Panduan bagi petugas teknis, penyuluh dan peternak. Kanisius, Yogyakarta

Auza, Astuti F. 2010. Efektifitas Pemberian serbuk Kunyit, Bawang Putih dan Mineral Zink Terhadap Kadar Kolestrol Darah dan Bobot Organ Dalam pada Broiler.Tesis.Program Studi Sistem-sistem Pertanian Konsentrasi Peternakan Program Pascasarjana Universitas Hasanuddin, Makassar.

Charoen Pokphand Indonesia. 2004. Feed and Nutrition In Broiler Management. Stadium General Charoen Pokphand, Fakultas Peternakan Institut Pertanian Bogor. Bogor.
Hetland, H., B. Svihus and M. Choctt. 2005. "Role of Insoluble Fiber on Gizzard Activity In Layers". J. Apply. Poultry Res.14: 38-46.

Khotimah, K. 2002. Pengaruh Ekstrak Jeruk Nipis dan Metode Pengolahan pada Kualitas Daging Pedaging.http://digilib.si.itb.ac.id/ print.php.id=jiptumm-gdl-Res2002-ir-5311-jeruk. Diakses: 1 agustus 2017.

Loth M.R. 2011. Penmbahan tepung kunyit (Curcuma domestika val) Dalam Ransum Komersial Terhadap Berat Organ Internal Ayam Pedaging. Laporan Hasil Penelitian. Universitas Sumatera Utara.

Mangisah, I. 2005. Pemanfaatan Kunyit (Curcuma demostika, val) atau temulawak (Curcuma xantorrhiza, roxb) untuk menurunkan kadar kolesterol Daging Broiler. Laporan Hasil Penelitian, Fakultas Peternakan, Universitas Sumatera Utara.

Mide, M.Z. 2007. Konversi Ransum dan Income Over Feed and Chick Cost Broiler yang Diberikan Ransum Mengandung Berbagai Level Tepung Rimpang Temulawak (Curcumin Xanthorrhiza Roxb). Buletin Nutrisi dan Makanan Ternak.6(2): 21-26.

Nickle, R.A., Scummer., E. Seiferle., W.G. Siller., and P.H.L. Wight. 1977. Anatomi of Domestic bird. Verlag Paul Parey, Berlin.

Ressang, A. A. 1993. Patologi Khusus Veteriner. Edisi ke-2.Bali. 
Riayadi, S. 1996. Bau kotoran dan CRD hilang. Majalah Invovet. 39: 3334.

Rukmana, R. 2006. Temulawak, Tanaman Rempah dan Obat. Penerbit Kanisius. Yogyakarta.

Salam. S., A. Fatahilah, D. Sunarti, dan Isroli.2013. Berat Karkas dan Lemak Abdominal Ayam Broiler yang diberi Tepung Jintan Hitam (Nigella sativa) dalam Ransum selama Musim Panas.Sains Peternakan.11(2): 84-89.

Sariati.2017. Pengaruh Pemberian Temulawak (Curcuma xanthorrhiza, Roxb) Dalam Pakan Terhadap Penampilan Produksi Ayam Broiler.Skripsi. Fakultas Peternakan. Universitas Halu Oleo.Kendari.

Setiadi, D., N. Khaira dan T. Syahrio. 2011. Perbandingan bobot hidup, karkas, giblet, dan lemak abdominal ayam jantan tipe medium dengan strain berbeda yang diberi ransum komersial broiler. Skripsi. Jurusan Peternakan. Fakultas Pertanian. Universitas Lampung. Lampung.

Sinurat, A. P., T. Purwadaria, I.A.K. Bintang, P.P. Ketaren, N. Bermawie, M. Raharjo dan M. Rizal. 2008. Pemanfaatan Kunyit dan Temulawak sebagai Imbuhan Pakan untuk Ayam Broiler.JITV. 14(2): 90-96.

Siregar, D.M. 2011. Persentase Karkas Dan Pertumbuhan Organ Dalam Ayam Broiler Pada Frekuensi Dan Waktu Pemberian Pakan Yang Berbeda.Skripsi, Departemen Ilmu Produksi dan Teknologi Peternakan. Fakultas Peternakan, Institut Pertanian Bogor.
Subeki K., H. Abbas., K.A. Zura. 2012. Kualitas Karkas (Berat Karkas, Persentase Karkas Dan Lemak Abdomen) Ayam Broiler yang Diberi Kombinasi CPO (Crude Palm Oil) dan Vitamin C (Ascorbic Acid) dalam Ransum sebagai Anti Stress. Jurnal Peternakan Indonesia.14 (3): 447453.

Suprayitno dan M. Indradji.2007. Efektivitas Pemberian Ekstrak Temulawak (Curcumae xanthoriza) dan Kunyit (Curcumae domestica) dan Sebagai Immunostimulator Flu Burung pada Ayam Niaga Pedaging. J. Animal Production.9: 178-183.

Sumarni. 2015. Pengaruh kuantitas ransum terhadap persentase karkas, giblet dan lemak abdominal ayam broiler. Skripsi. Fakultas Peternakan. Universitas Halu Oleo.Kendari.

Sturkie, P.D. 2000. Avian Psiology.Edisi ke-15. Spinger-Verlag, New York.

Suyanto, D., Achmanu dan Muharlien. 2013. Penggunaan tepung kemangi (ocimum basilicum) dalam pakan terhadap bobot karkas, presentase organ dalam dan kolesterol daging pada ayam pedaging. Skripsi. Fakultas Peternakan Universitas Brawijaya. Malang.

Wijayakusuma, M. H. 2005. Kunyit dan Temulawak untuk Mencegah Flu Burung. 